\title{
Effects of Different Turbulators on Heat Transfer in Smoke Tube Boilers and Modeling of These Effects with Machine Learning Algorithms

\author{
Aydın ÇITLAK ${ }^{1 *}$, Ahmet Beyzade DEMIRPOLAT ${ }^{2}$
}

\begin{abstract}
In smoke pipe boilers, the thermal efficiency of the boiler depends on the smoke pipe diameter, smoke pipe length and the heat transfer between the smoke pipe and the outlet chimney. If the heat in the smoke pipes is effectively transported through the pipes, the heat distribution on the surfaces is balanced and the thermal efficiency of the boiler increases. In this study, the improvement of heat transfer in a solid fuel boiler with $125,000 \mathrm{kcal} / \mathrm{h}$ heat capacity with a diameter of $42 \mathrm{~mm}$, chimney diameter of $230 \mathrm{~mm}$ and water inlet and outlet diameters of $65 \mathrm{~mm}$ was investigated by using 4 different types of strip turbulators. Experiments were carried out with turbulators placed in all the smoke pipes in the boiler. Firstly, experiments were carried out without placing a turbulator inside. In the second step, by placing turbulators in the smoke pipes, experiments were made for each type and heat transfer was calculated. In the experiments, the flow rate of the fan was changed with the help of damper and the reynolds number was calculated between 18000 and 28000 . Turbulator experiments for heat transfer improvement have increased by at least $\% 15$ and at most $\% 41$ compared to turbulator free experiments. For the heat transfer increase values obtained because of calculations, predictive models were obtained using machine learning algorithms SVM (support vector machine) and decision tree (M5P model tree). The resulting models have been analyzed for error analysis and have been shown to successfully predict heat transfer increase values.
\end{abstract}

Keywords: Smoke tube boiler, heat transfer, turbulator, pressure difference, support vector machine, M5P model tree

\footnotetext{
${ }^{1}$ Aydın ÇITLAK (Orcid ID: 0000-0002-6837-4178), Firat University, Faculty of Engineering, Department of Mechanical Engineering, Elazig, Turkey

${ }^{2}$ Ahmet Beyzade DEMIRPOLAT (Orcid ID: 0000-0003-2533-3381), Turgut Özal University, Arapgir Vocational School, Electronics and Automation Mechatronics Program, Arapgir, Malatya, Turkey

*Sorumlu Yazar/Corresponding Author: Aydın ÇITLAK, e-mail: acitlak@ firat.edu.tr
} 


\section{INTRODUCTION}

Increasing the performance of a heat exchanger; it is possible by bringing the hot fluid temperatures at the outlet of the heat exchanger and the cold fluid temperatures at the inlet as close as possible. The closer the hot and cold fluid temperatures are the better the performance of the heat exchanger. However, during this approach, pressure losses will increase. Increasing pressure losses will increase operating costs. For this reason, the increase of heat transfer should be taken into consideration in the design of heat exchangers. Increasing the heat transfer coefficient is possible by mixing the flow that is increasing the turbulence. Heat transfer is higher in turbulent flow than laminar flow. This is because the fluid particles flow in layers over each other in the laminar flow. This affects the heat transfer negatively. In turbulent flow layers do not form and heat exchange increases between fluid particles (Karakaya and Durmuş, 2013; Panahi and Zamzamian, 2017).

The use of turbulators (turbulence generators) has become widespread to increase the heat transfer and thus the efficiency of the boiler in the industrial type boilers and heating boilers with smoke pipes. The fact that the results obtained from the turbulators are serious in terms of lowering the annual energy costs have pushed both engineers and manufacturers into the search for new turbulator models. Thus, studies in this area have gained speed and many experimental and numerical studies have been done for the most suitable turbulator geometry and material (Sparrow and Chaboki , 1984; Verma et al., 2017). To increase the performance of Sungur and Topaloğlu smoke tube boiler systems; they have numerically investigated the change in the heat transfer of the system by installing turbulators conically to the smoke pipes in the system (Sungur and Topaloğlu, 2018). Akeel et al. Experimentally investigated the increase of forced convection heat transfer by passive techniques for a turbulent air flow in this aluminum test tube; reynolds number range is between 6000 and 13500 and applied constant heat flux boundary conditions. They achieved significant improvements in heat transfer using different divergent nozzle turbulators with and without holes (triangular holes, square holes, and circle holes) (Akeel et al., 2014) . In order to examine the effect of turbulators on heat transfer in a horizontal pipe, Karagöz and his colleagues first installed fins in the pipe in order to create a turbulent flow and compared the unprocessed pipe to compare the data obtained.While performing these experimental operations, they used different turbulators with different vane distances and angles and carried out their studies in various reynolds numbers (Karagöz et al., 2017). In Kayataş and İlbaş studies, to examine the change of heat transfer, they installed fins of different geometries on a nested heat exchanger. They examined the data obtained against the eddy flow and the effect of heat transfer by applying the same directional and opposite flows on the finless heat exchanger and numerically examined these effects with the help of the fluent program (Kayataş and İlbaş, 2005). In Argunhan and Y1ld1z studies, by using rotation manufacturers with different hole numbers in a nested heat exchanger; they experimentally investigated changes in the system on heat transfer and pressure drop (Argunhan and Y1ldiz, 2011). They mounted the fins on aluminum tubes to create turbulence and compared the effects of this application relative to the empty tube. They conducted their investigations in different Reynold numbers using three arcs with three ranges and three bent plates (Karagöz et al.,2019). They have installed a helical turbulator inside a Copper pipe and examined the change of the effect of this application on heat transfer using numerical methods (Uğurlubilek and Uralcan,2011). Sungur et al. Investigated increasing the efficiency of liquid fuel smoke tube boilers used in domestic heating. For this purpose, they placed conical geometry turbulators in the boiler's smoke pipes and investigated the effects on the flame structure and heat transfer numerically. Calculations were carried out in two dimensional axisimetric conditions and fluent was used as computational fluid dynamics software. 
Temperature and flow function distribution and pressure drop according to the arrangement of the turbulators were examined and they investigated the most suitable turbulator for the boilers (Sungur et al.,2018). Şahin and Dal used a spring-type turbulator to improve the heat transfer and determine the friction characteristics of a concentric nested tube heat exchanger and made numerical analyzes with the RNG k- $\varepsilon$ model (Şahin et al.,2020).

In the literature, various studies have been carried out in order to increase the heat transfer in the pipe, theoretically and experimentally in rotational flows. Smithberg and Landis investigated heat transfer and friction losses by using bent type spinning rotors built into the pipe in forced transport (Smithberg and Landis,1964). The researchers determined that the speed field of the flux is helical and the vortex in the core of the flux using the twisted type rotational manufacturer. They observed that these formations had a positive effect on heat transfer. (Narezhnyy and Sudarev,1971) They used helically twisted turbulators as a rotating flow generator. The researchers placed the turbulators at the inlet of the pipe, instead of placing it all over the pipe. In this way, the flow was initially rotated, and then allowed to develop independently. Thus, they ensured that the pressure losses did not increase excessively in addition to the increase in heat transfer. (Migay and Golubev,1970) They investigated heat transfer and friction losses if there are rotating flow generators in the pipe and the inlet flux is turbulent. According to researchers, heat transfer increases in rotational flows, but the friction coefficient has increased even more than heat transfer. In other words, rotating flows increase the heat transfer, while increasing the pressure losses. Kuzay and Scott conducted experimental studies for turbulent heat transfer in the case of both rotating and standing inner cylinders in a cylindrical range (Kuzay and Scott,1977). The researchers measured speed components and hydraulic losses over time if a fully developed turbulent flux was supplied to an axially rotating pipe (Kikuyama et al.,1983). Researchers have found that rotating the pipe suppresses turbulence and reduces hydraulic losses. In this case, they observed that the axial velocity approached a laminar flow type with an increase in the rotational speed of the pipe. Y1ldiz and others investigated the effect of the crimped strip placed in a concentric double tube heat exchanger on heat transfer and pressure loss (Y1ldiz et al.,1998). Experiments were carried out for both simultaneous and counter flow conditions. In the double-pipe air-cooled system, heat transfer was increased $100 \%$ by placing a turbulator in the form of a curved strip inside the tube.

Many data and formulas are used for heat transfer research. Processing large data and getting results are very time consuming and laborious. In this respect, variety computational intelligence methods are used to process many data. The most common of these methods are artificial neural networks. Artificial neural networks have been applied to many studies on heat transfer. Moya-Rico and friends created an artificial neural networks (ANN) model with corrugated and inner tubes that can accurately predict the heat transfer rate and pressure drop in a triple concentric tube heat exchanger typically used in the food industry (Moya-Rico et al.,2019). They developed and validated the ANN model using a database containing 181 experimental datasets. The ANN configuration consists of a network with two hidden layers of 15 and 21 neurons in the first and second layers, respectively. They found that the ANN results were in good agreement with the experimental data, the absolute average relative deviation (AARD) was below $1.91 \%$ for the heat transfer coefficient and below $3.82 \%$ for the pressure drop. Verman and others compared the heat transfer performance of the proposed fabricated heat exchanger using corrugated and non-corrugated pipes. The length and diameter of the pipes are $25.4 \mathrm{~mm}$ and $2000 \mathrm{~mm}$, respectively. The authors also modeled the artificial neural network (ANN) to estimate the heat transfer coefficient, nusselt number, and reynolds number (Verma et al., 2017). 
Durmuşoğlu and his colleagues have designed a compatible artificial neural network model to accurately predict the nusselt number and friction factor of a perforated strip element placed in the pipe. Guoqiang experimentally examined heat transfer in the $180^{\circ}$ return channel with variable cross section and different turbulators. The channel is the middle part of a gas turbine blade. He analyzed the heat transfer of the duct inside a gas turbine blade both experimentally and predictively using ANN (Guoqiang, 2007; Golgiaz et al.,2019). Golgiaz and others presented an experimental study on the prediction of flue gas temperature in a small-scale hazelnut fired burner. They obtained attributes from the flame image and made ANN flue gas temperature estimation with image processing method (Golgiyaz et al.,2019). Çirak and Korçak examined heat transfer and heat losses by using two different artificial neural network (ANN) models for insulated and uninsulated conditions of the heating pipes used for heating in buildings (Çirak and Korcak,2017). Tokgoz and friends used the fluid dynamics (CFD) package program to calculate the flow values of nanofluids in the system. They performed their work in the reynolds range of $10,000 \leq \mathrm{Re} \leq 20,000$ They calculated the thermal and hydraulic properties of the nanofluid flowing through a straight channel in order to verify their numerical estimates (Tokgoz et al.,2018). Koca and Zedeli have been experimentally considered to increase the heat transfer by vertical positioning of the helical inner tube heat exchanger with different helical numbers and they have investigated to improve the heat transfer by increasing the number of helical copper pipes used in the heat exchanger ( Koca and Zedeli,2020).

Ibrikçi and friends used artificial neural networks (ANN) to accurately estimate the critical buckling loads of a cylindrical isotropic spiral spring with a fixed end and circular cross section and found that the data obtained corresponded with the literature ( İbrikçi et al.,2010).

The aim of this study is to investigate the effects of the turbulator types produced on heat transfer in a solid fuel boiler and to improve the heat transfer. For this purpose, increase and pressure loss in heat transfer was investigated by developing and placing different types of turbulators into the pipe in smoke tube boilers. In this way, the effects of different turbulators on heat transfer were examined. By placing turbulators at the pipe inlet and along the pipe, heat transfer changes were obtained for different reynols values. Necessary arrangements have been made to deliver the required water and hot smoke to the system. A fan is used when necessary to obtain the air flow drawn through the smoke pipe. The temperature of the pipes and the fluids were read with thermo elements, a channel selector and temperature gauges. Pressure losses were determined at certain points on the system by reading the pressure values. Heat transfer increases were achieved with four types of turbulators used in smoke ducts. For the obtained heat transfer increase values, the predictive model was developed by using the M5P model tree algorithm, the machine learning algorithm. To determine the validity of the predictive model, mean absolute error (MAE), root mean square error (RMSE), relative absolute error (RAE) and root relative absolute error (RRAE) analyzes were performed. In this study, it is expected that the studies on the pressure losses, heat transfer increase and design of the smoke tube boilers can serve as an example to predict some thermophysical properties by using machine learning algorithms.

\section{MATERIALS AND METHODS}

\section{Experimental Setup}

Experimental studies, Malatya Mimsan Ltd. STI. It was made with the experimental setup established in the boiler factory. Schematic view of the experimental setup is given in Figure 1 (Çıtlak et.al.,2019). 


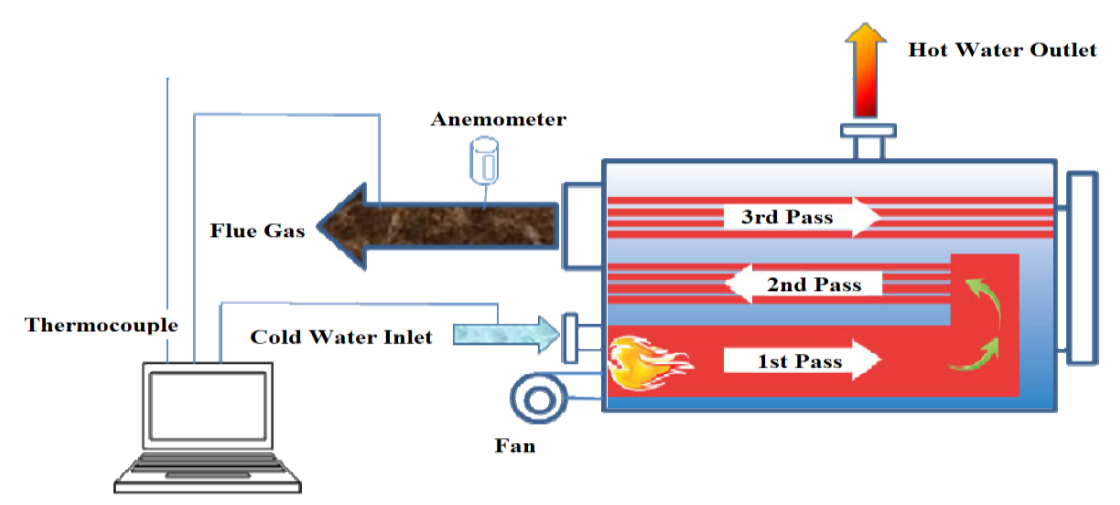

Figure 1. Schematic view of the experimental setup.

In the experimental setup;in order to obtain hot water, 3 pass boiler with $125.000 \mathrm{kCal} / \mathrm{h}$ capacity with solid fuel Mimsan brand, multi-input computer controlled temperature meter measuring temperature at various points, anemometer for flue gas speed and electronic differential pressure device for pressure difference. The diameter of the boiler's smoke pipes is $42 \mathrm{~mm}$, the chimney diameter is 230 $\mathrm{mm}$, and the water inlet and outlet diameters are $65 \mathrm{~mm}$. T type $0.5 \mathrm{~mm}$ teflon insulated copper $(\mathrm{Cu}-$ Cons) placed in water inlet and outlet and flue gas was measured with thermocouples. 32 channel Elımko digital scanner was used for temperature and pressure measurements. Chimney gas velocity was measured with an anemometer attached to the chimney. In addition, a circulating pump for circulating heated water in the test system and flanged type magnetic rotameter to measure the flow rate of the circulating water is attached to the pipe. One of the ways to increase heat transfer is to install turbulators in the smoke pipes in the system. In the experiments, a total of 8 turbulators of 4 different types were used. In addition, measurements were taken without turbulators for all $\operatorname{Re}$ numbers. Walnut sized russian lignite coal was used as fuel. Pictures of the experiment set are given in figure 2 and figure 3.

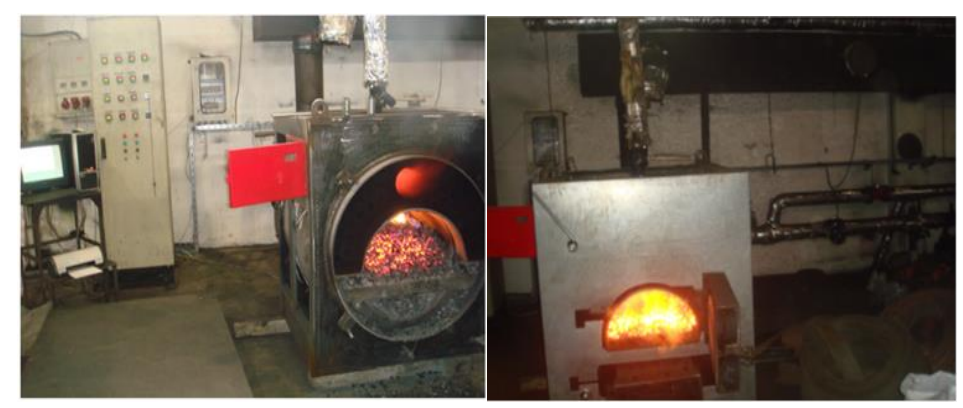

Figure 2. The boiler and automation system used in the experiments

The turbulators are made of $2 \mathrm{~mm}$ sheet metal and shaped in the press by heating. Turbulators are produced in two types as curved and wavy. The turbulators used in the experimental study were manufactured with a length of $45 \mathrm{~cm}$ and experimental data were obtained using these turbulators. (Figure 3). 

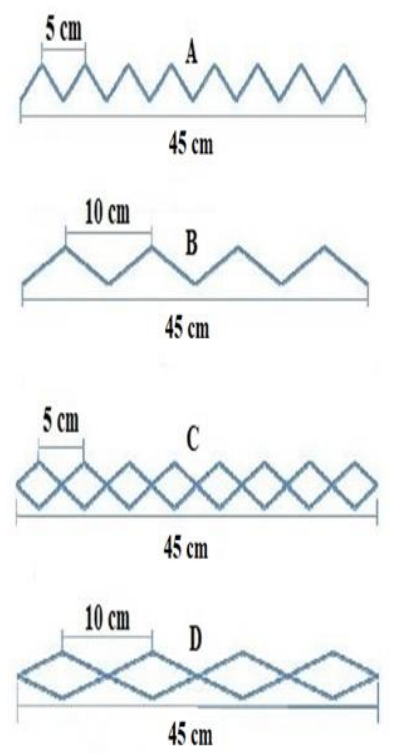

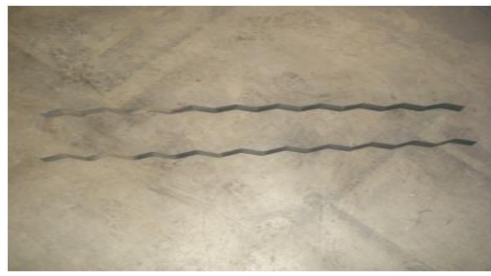

$\mathbf{E}$

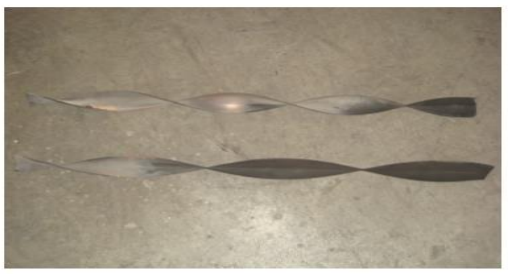

D

Figure 3. Types of turbulators (A-E: Frequent wave, B: Sparse wavy, C-D: Freely curved, D: Sparse curved)

\section{Calculation Procedure}

The fan used in the boiler provides $1650 \mathrm{~m}^{3} / \mathrm{h}, 1050 \mathrm{~m}^{3} / \mathrm{h}$ and $700 \mathrm{~m}^{3} / \mathrm{h}$ air flow with the help of damper. The number of boiler smoke pipes is 34 pieces. The volume flow through each smoke pipe with a diameter of $42 \mathrm{~mm}\left(\mathrm{D}_{\mathrm{i}}\right)$ is determined by the ratio of the flow rate to the number of smoke pipes. Re number was found with the help of Equation (1) (Y1lmaz and Ayhan,1983).

$$
\operatorname{Re}=\frac{U \cdot D i}{v}
$$

In Equation (1), $v$ is the kinematic viscosity of the air, the inner diameter of the $D_{i}$ pipe, the average velocity in the $U$ smoke pipe. In the study, measurements were made in 3 different flow rates in the range of $\mathrm{Re}=18000-28000$.

The amount of heat $\left(\mathrm{Q}_{1}\right)$, which consists of hot smoke gas inside the pipe and passes into the water on the outer surface of the pipe, has been found by using Equation (2) (Kakaç,1987). This amount of heat is also equal to the amount of water $\left(\mathrm{Q}_{2}\right)$ in the pipe.

$$
\mathrm{Q}_{1}=\mathrm{Q}_{2} \mathrm{Q}_{1}=\text { h.A. } \Delta \mathrm{T} \log
$$

In finding the logarithmic temperature difference values of the smoke pipes, the calculations in Figure 4 and Equation (3) are used. 


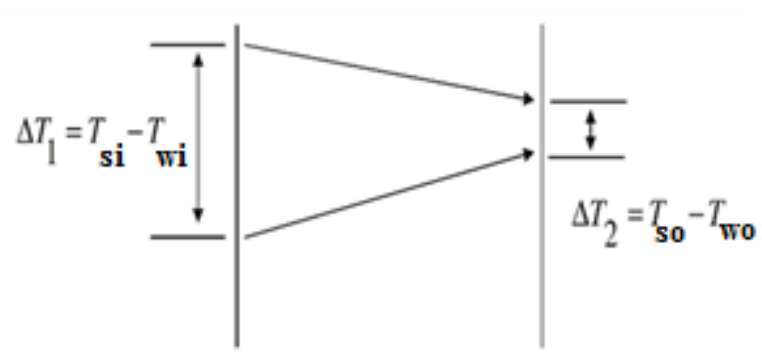

Figure 4. Logarithmic temperature difference

In Figure 4; $\mathrm{T}_{\mathrm{si}}=$ The entrance temperature of the smoke to the burner (Front chest temperature), $\mathrm{T}_{\mathrm{so}}=$ The exit temperature of the smoke from the burner (Back chest temperature), $\mathrm{T}_{\mathrm{wi}}=$ The temperature of the water entering the boiler, $\mathrm{T}_{\mathrm{wo}}=$ The temperature of the water leaving the boiler.

The logarithmic temperature difference was calculated with the help of Equation (3).

$$
\Delta \mathrm{T}_{\log }=\frac{\Delta \mathrm{T}_{1}-\Delta \mathrm{T}_{2}}{\ln \left(\frac{\Delta \mathrm{T}_{1}}{\Delta \mathrm{T}_{2}}\right)}
$$

Equation (2) also shows the heat transfer coefficient $h$, the side surface area (thermal area) of the pipe where the flux A passes. The amount of heat $\left(\mathrm{Q}_{2}\right)$ of the water in the pipe is found with the help of Equation (4).

$$
Q_{2}=\dot{m}_{\text {water }} c_{p_{\text {water }}}\left(T_{s g}-T_{s \zeta}\right)
$$

In equation (4), $\dot{\mathrm{m}}_{\text {water }}$ is the mass flow of water $(\mathrm{kg} / \mathrm{sec})$, and $\mathrm{C}_{\text {pwater }}$ is the specific $(\mathrm{J} / \mathrm{kgK})$ heat of water. After logarithmic temperature difference is obtained, energy balance and average heat transfer coefficient are calculated. The heat gained with the help of equation (5) is found by hitting the heat generated by the temperature difference in the surface area.

$$
\begin{gathered}
\mathrm{Q}_{1}=\mathrm{Q}_{2} \\
\text { h.A. } \Delta T_{\log }=\dot{m}_{\text {water }} c_{p_{\text {water }}}\left(T_{s g}-T_{s c ̧}\right)
\end{gathered}
$$

The coefficient $\mathrm{h}$ in Equation (5) is calculated with the help of Equation (6).

$$
h=\frac{(\dot{V} \cdot \rho)_{\text {water }} c_{p_{\text {wate }}}\left(T_{s g}-T_{s c}\right)}{\left(\pi D_{i} L\right) \cdot \Delta T_{\log }}
$$

In Equation (6), the volumetric flow is the side surface area of the smoke pipe A and the inner diameter of the smoke pipe Di. With the help of $h$ heat transfer coefficient ( $\mathrm{W} / \mathrm{m}^{2} \mathrm{~K}$ ) in Equation (6), the Nusselt number is calculated with the help of Equation (7). 


$$
N u=\frac{h L}{k}
$$

In equation (7), $\mathrm{h}$ is the heat transfer coefficient, $\mathrm{L}$ is the length of the pipe and $\mathrm{k}$ is the heat conduction coefficient of the air. The increase in the number of $\mathrm{Nu}$ thanks to turbulators shows that there is an increase in heat transfer. However, due to its structure, turbulators create resistance to flow, which causes an increase in pressure loss. For this purpose, it is necessary to determine the net heat gain and additional pressure loss amount to determine the heat gain rate. To determine the Thermal Gain rate, the corresponding Equation (8), which is the ratio of the Net heat gain to the additional pressure loss, can be applied (Çakmak,2000).

$$
\frac{Q_{N I K}}{\Delta P_{K}}=\frac{Q_{T}-Q}{\Delta P_{T}-\Delta P} \cdot \frac{1000}{\dot{V} \cdot 9,81}
$$

The amount of heat transferred in equation (8) in $\mathrm{Q}_{\mathrm{T}}$ turbulator experiments is the amount of heat transferred in the experiment without $\mathrm{Q}$ turbulators. The pressure difference that occurs in experiments with $\mathrm{P}_{\mathrm{T}}$ turbulator shows the pressure difference in experiments without $\mathrm{P}$ turbulator. volume flow. Equal (8) dimensionless thermal gain value is obtained.

In order to see an increase in the heat transfer analysis compared to the test without turbulators, percentage increases were found by using Equation (9).

$$
\% Q h=\frac{Q_{T}-Q}{Q}
$$

Equation (9) shows the amount of heat transferred in $\mathrm{Q}_{\mathrm{T}}$ turbulator experiments and the amount of heat transferred in experiments without $\mathrm{Q}$ turbulators. This calculation was applied to all results of the experiments, and the results of the experiments with the turbulator were increased in percent compared to the test without turbulator.

In the experiment study, the performance of the heat transfer was measured. Reynolds numbers and friction factor were calculated with the values obtained from these measurements. These calculated values of the uncertainty value determining Kline and McClintock direction specified by the tem (Equation 10) is based on (Kline, 1953; Holman, 1989). In Equation 10, x denotes uncertainty properties and $\mathrm{W}$ denotes uncertainty value. In this study, the uncertainty analysis calculated for various parameters is shown in Table 1.

$$
\mathrm{W}_{\mathrm{x}}=\left[\left(x_{1}\right)^{2}+\left(x_{2}\right)^{2}+\ldots \ldots \ldots \ldots\left(x_{\infty}{ }^{2}\right)\right]^{1 / 2}
$$


Table 1. Uncertainty Values

\begin{tabular}{ll}
\hline Parameter & Uncertainty Value (\%) \\
\hline Heat Transfer Loss Measurements & $\pm 4.1 \%$ \\
Mass and time measurements & $\pm 1.3 \%$ \\
Uncertainty due to differences in smoke pipe length & $\pm 1.1 \%$ \\
Uncertainty due to differences in pipe diameter & $\pm 1.2 \%$ \\
Uncertainty of Physical Properties (Viscosity and Density) & $\pm 1.3 \%$ \\
The uncertainty in the Reynold number & $\pm 2.9 \%$ \\
Uncertainty in the friction factor & $8.2 \%$ \\
\hline
\end{tabular}

\section{Decision Tree Algorithm}

The decision tree (DT) algorithm is a classification and pattern identification algorithm that has been widely used in the literature in recent years. The most important reason for the widespread use of this method is that the rules used to create tree structures are understandable and simple the basic structure of a decision tree consists of three basic parts called knots, branches, and leaves, as shown in Figure 5. In this tree structure, each attribute (Air speed, Temperature, etc.) is represented by a knot Branches and leaves are other elements of the tree structure. The last part of the tree and the top of the tree are called roots (Alic et.al.,2019; Pal and Mather,2003). The parts between the roots and leaves are expressed as branches (Das and Demirpolat,2019; Çerçi and Daş,2019). In other words, a tree structure; a root node containing data, internal nodes (branches) and end nodes (leaves). The basic principle in creating a decision tree structure using the attribute information of the training data can be expressed as a series of questions about the data and can be concluded by concluding according to the answers obtained as soon as possible. In this way, the decision tree collects answers to questions and creates decision rules. The root node, the first node of the tree, begins to ask questions for classifying data and the structure of the tree, and this process continues until branches without or without knots are found (Demirpolat and Das, 2019).

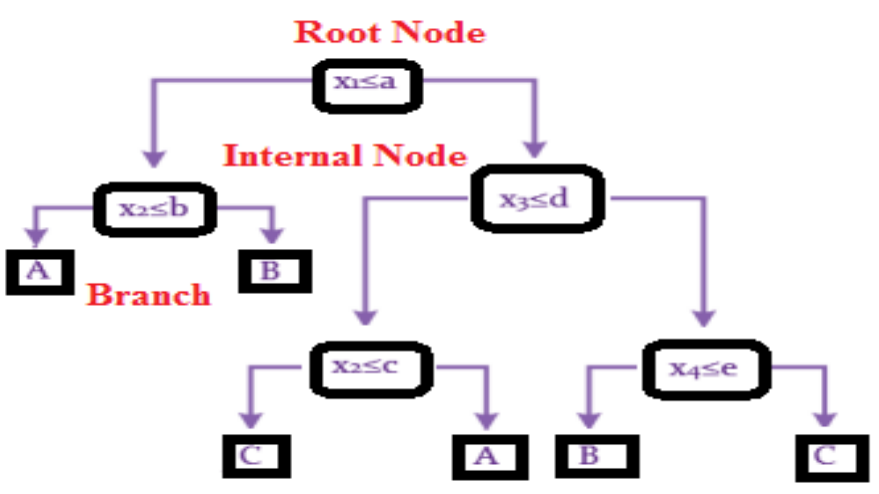

Figure 5. DT structure consisting of three classes with four-dimensional feature areas

Figure 5 shows a simple tree structure consisting of four-dimensional property values of three classes. Figure $x_{i}$ property values; Values $A, b, c, d$, and e represent branching and threshold values for A, B, C class labels.

Turbulator length (Size), Reynolds number $(\mathrm{R})$ value, Nusselt number $(\mathrm{Nu})$ value, pressure drop $(\Delta \mathrm{P})$, Heat gain / Pressure Loss rate $\left(\mathrm{Q}_{\text {gain }} / \mathrm{P}_{\text {loss }}\right)$ values input information used to create the predictive model in decision tree algorithm taken as. Heat transfer $\%$ increase $\left(\% \mathrm{Q}_{\mathrm{h}}\right)$ was used as output information. KA algorithm, which is used to estimate the increase in heat transfer of the smoke tube boiler, has been applied using MATLAB 2018b software. M5P algorithm is used for KA method in MATLAB software. 
Figure 6 shows the tree structure used by the decision tree algorithm to estimate $\% \mathrm{Q}_{\mathrm{h}}$ values. In Figure $6, \% \mathrm{Q}_{\mathrm{h}}$ value is calculated according to rules in tree branches depending on Size, Re and $\mathrm{Nu}$ values in decision tree.

In Figure 6, the turbulator length (Size) parameter forms the root part of the tree and the inner node, $\mathrm{Re}$ and $\mathrm{Nu}$ branches. The part number 1-4 forms the leaves. The KA algorithm continues to apply rules until the data is separated by decisions in the branches and reaches leaf values. The KA algorithm randomly sets the rules and roots.

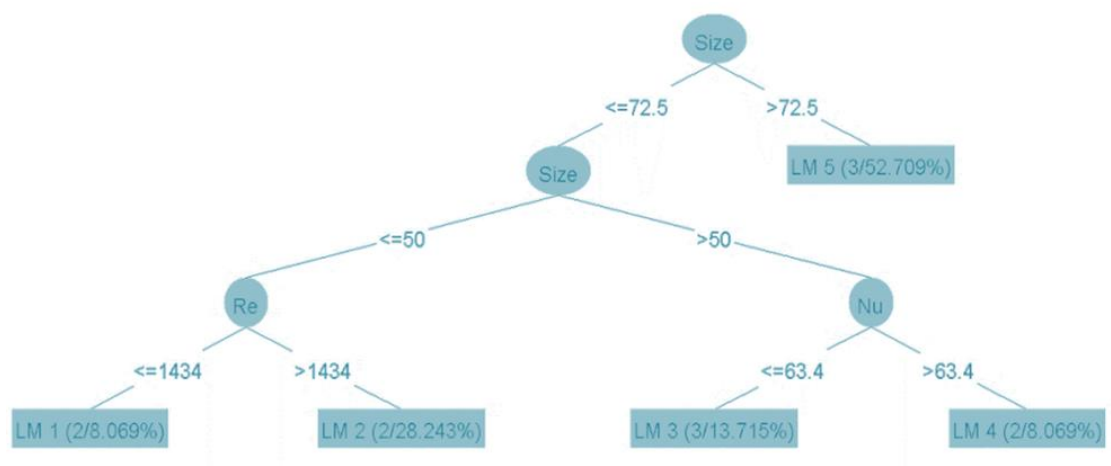

Figure 6. M5P Tree structure

\section{Support Vector Machine}

The Support Vector Machine (SVM) is an excellent kernel-based tool for classification and regression (Vapnik,1998;Das and Akpınar,2018).This learning strategy has been developed by Vapnik and is a very powerful method based on principles in machine learning algorithms (Smola and Schölkopf,2004). A comprehensive study on the use of support vector machines in the solution of regression problems was done by Smola and Schölkopf (Vapnik,1995). It is given $\left[\left(\mathrm{xi}_{\mathbf{i}}-\mathrm{yi}_{\mathbf{i}}\right)\right]_{\mathbf{i}=1}^{\mathbf{N}}=\mathbf{1}$ in the form of training examples. In regression problems, the response variable is defined as $y i \in \mathbb{R}$ instead of $y i \in\{+1,-1\}$. SVMs divide the data from linear and nonlinear forms into 2 groups and perform the estimation or classification process accordingly. In nonlinear datasets, SVM can make predictions thanks to its kernel functions. In this study, PUK kernel was used in SVM algorithm. The PUK kernel function is shown in Table 2 (Das et.al.,2019).

Tablo 2. The PUK kernel function and parameters used in SVM

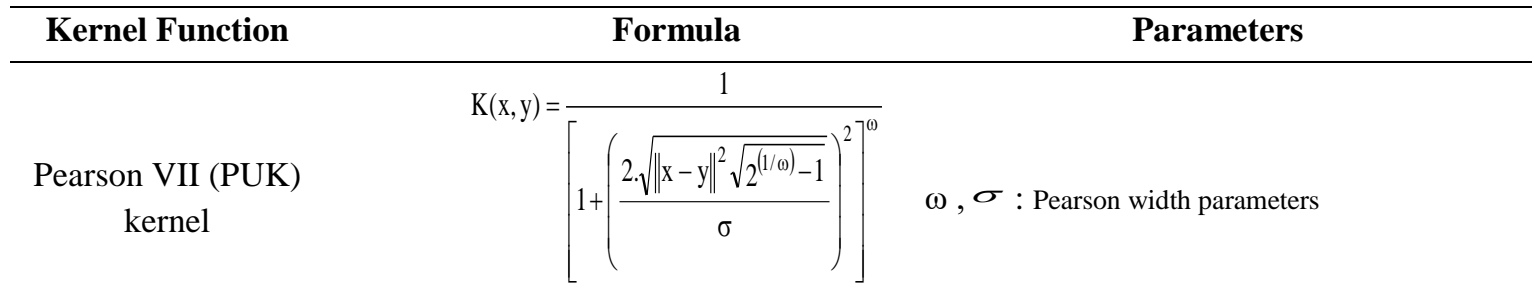

The input and output parameters of the model created with the decision tree algorithm are used in the SVM algorithm model. Error analysis of the models created by the decision tree and SVM algorithms are shown in Table 3. The formulas and parameters of the error analysis are given in Table 3. 
Table 3. Error Analysis, Formulas and Parameters

\begin{tabular}{|c|c|c|}
\hline Error Analysis & Formula & Parameters \\
\hline MAE & $\frac{\left|P_{1}-A_{1}\right|+\ldots .+\left|P_{n}-A_{n}\right|}{n}$ & $\begin{array}{l}\text { P: Estimated Value } \\
\text { A: Real Value } \\
\text { n: Total Data }\end{array}$ \\
\hline RMSE & $\sqrt{\frac{\left(P_{1}-A_{1}\right)^{2}+\ldots . .+\left(P_{n}-A_{n}\right)^{2}}{n}}$ & $\begin{array}{l}\text { P: Estimated Value } \\
\text { A: Real Value } \\
\text { n: Total Data }\end{array}$ \\
\hline RAE & $\frac{\left|P_{1}-A_{1}\right|+\ldots \ldots+\left|P_{n}-A_{n}\right|}{\left|A_{1}-A^{\prime}\right|+\ldots . .+\left|A_{n}-A^{\prime}\right|}$ & $\begin{array}{l}\text { P: Estimated Value } \\
\text { A: Real Value } \\
\text { A': Actual Value Avg. }\end{array}$ \\
\hline RRAE & $\sqrt{\frac{\left(P_{1}-A_{1}\right)^{2}+\ldots \ldots+\left(P_{n}-A_{n}\right)^{2}}{\left(\mid A_{1}-A^{\prime}\right)^{2}+\ldots . .+\left(A_{n}-A^{\prime}\right)^{2}}}$ & $\begin{array}{l}\text { P: Estimated Value } \\
\text { A: Real Value } \\
\text { A': Actual Value Avg. }\end{array}$ \\
\hline
\end{tabular}

\section{RESULTS AND DISCUSSIONS}

Graphs between $\mathrm{Re}$ number and $\mathrm{Nu}$ number among the values obtained as a result of experimental studies and calculations are given in Figure 7.

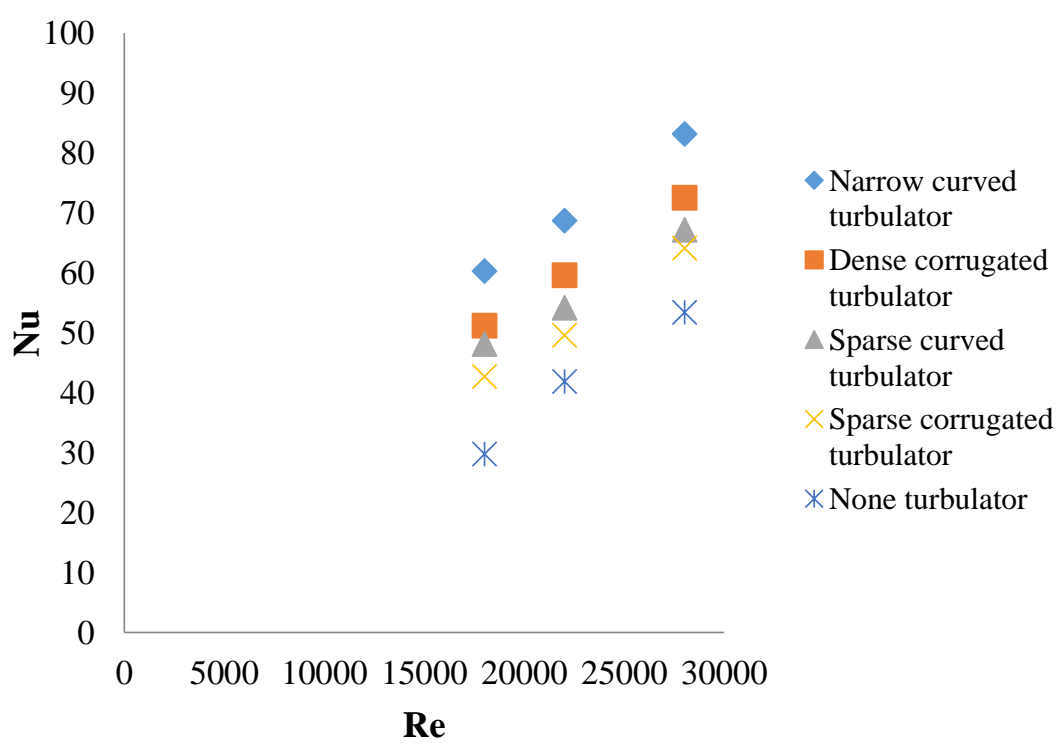

Figure 7. Variation of Re number with $\mathrm{Nu}$ number according to the characteristics of turbulators

As seen in Figure 7, the highest Nusselt number values were obtained in the frequently curved turbulator. In Figure 7, the highest Nusselt value was found as 97.5 in the calculations made at 28000 Re as a result of experiments done with a curved turbulator. Improvements were made in heat transfer by using turbulators in the boiler. Since this improvement in heat transfer is important with the pressure loss, the graph of the change in the number of Re with the difference in pressure is given in Figure 8 . 


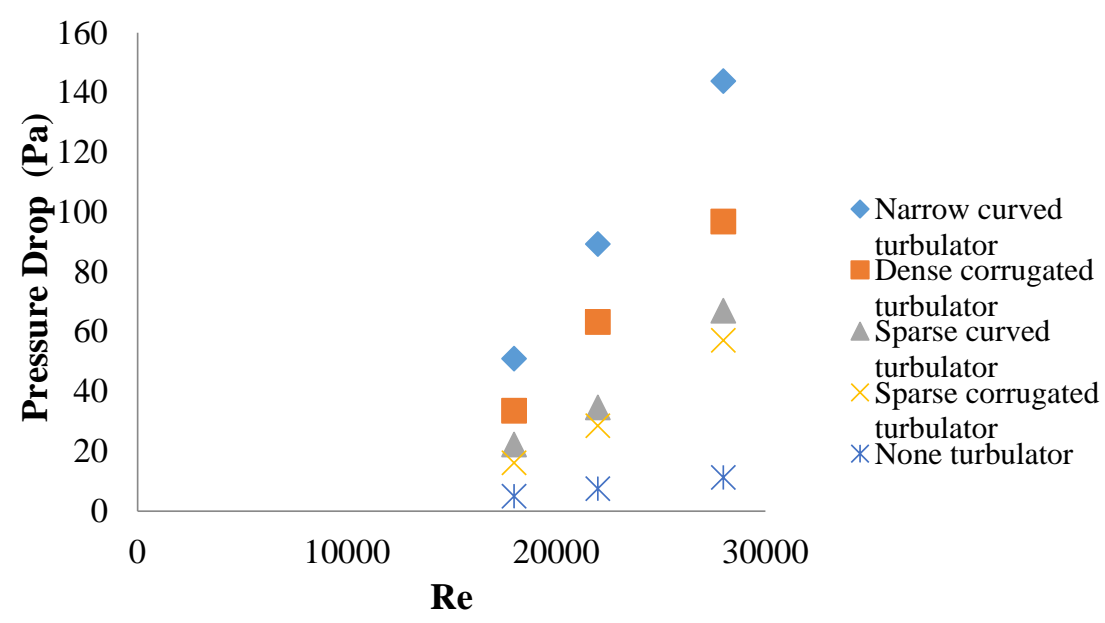

Figure 8. Variation of Re number with $\Delta \mathrm{P}$ according to the characteristics of turbulators.

As seen in Figure 8, the highest-pressure loss at $28000 \mathrm{Re}$ was found as $180.3 \mathrm{~Pa}$ in the frequently curved turbulator. From the values calculated in Equation 3-5, the ratio of the net heat gain to the net pressure drop and the number of Re changes are given in Figure 9.

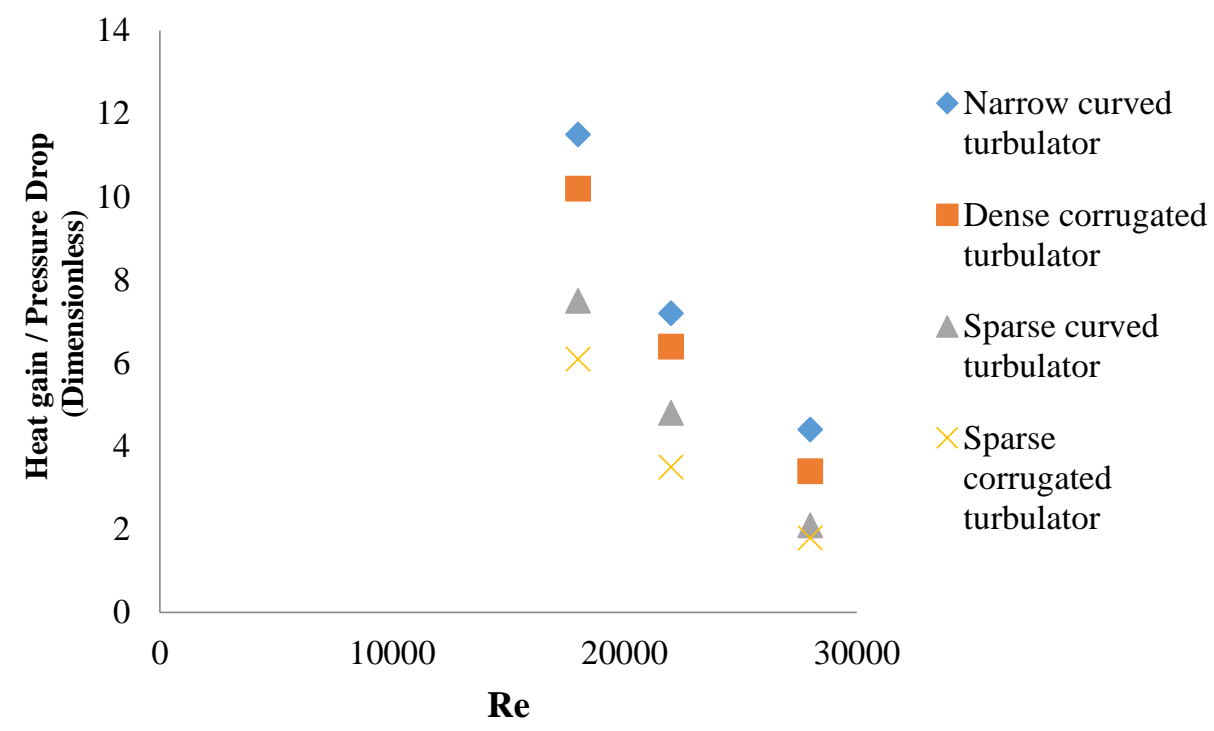

Figure 9. Changing the net heat gain / additional pressure loss rate with the number of Re according to the characteristics of the turbulators

The results of the tests carried out without turbulator and heat transfer compared with the turbulator are shown in Table 4.

Table 4. Percentage increase rate of heat transfer in the experiment using turbulator compared to the turbulatorless experiment.

\begin{tabular}{lc}
\hline Turbulator Types & Percentage heat transfer increase rate \\
\hline Frequent Wave Turbulator & $\% 24-\% 26$ \\
Sparse Turbulator & $\% 15-\% 17$ \\
Crimp Turbulator & $\% 41-\% 43$ \\
Rare Curved Turbulator & $\% 22-\% 24$ \\
\hline
\end{tabular}

As seen in Table 4 above, improvements in heat transfer up to $43 \%$ have been achieved. This rate of increase was seen in the frequently curved turbulator. The least increase was in the rare wave turbulator with $15 \%$. However, the most pressure loss also occurred in the frequently curved turbulator. The least heat transfer 
and the least pressure loss increase occurred in the sparse wave turbulator. The error analysis values of the model obtained with the M5P and SVM algorithms created for the heat transfer increase values obtained from the experiment set are shown in Table 5.

Table 5. Error rates

\begin{tabular}{ccc}
\hline Error Analyzes & M5P & SVM \\
\hline MAE & 3.1153 & 0.0439 \\
RMSE & 3.7421 & 0.0486 \\
RAE & $\% 31.8607$ & $\% 0.4487$ \\
RRAE & $\% 30.1962$ & $\% 0.3918$ \\
\hline
\end{tabular}

Chokkıyee and friends, the heat exchanger used in studies; used in multiple regression analysis studies to precisely estimate the values of nusselt numbers of $\mathrm{Al}_{2} \mathrm{O}_{3} / \mathrm{H}_{2} \mathrm{O}$ nanofluid flowing through it. After evaluating the results of these analyzes with root mean square error method (RMSE), they determined that the linear regression method (LM) used provided the best fit with the experimental data (Chokk1yee et al.,2020). Abadi and others Used the mean absolute error (MAE) method to determine the accuracy of the results of heat transfer coefficients and pressure drops obtained from the system (Abadi et al.,2018). Predictive models were created with M5P and SVM algorithms for heat transfer increase obtained with experiment data. The heat transfer increase values calculated with the predictive heat transfer increase values obtained are shown in Figure 10.

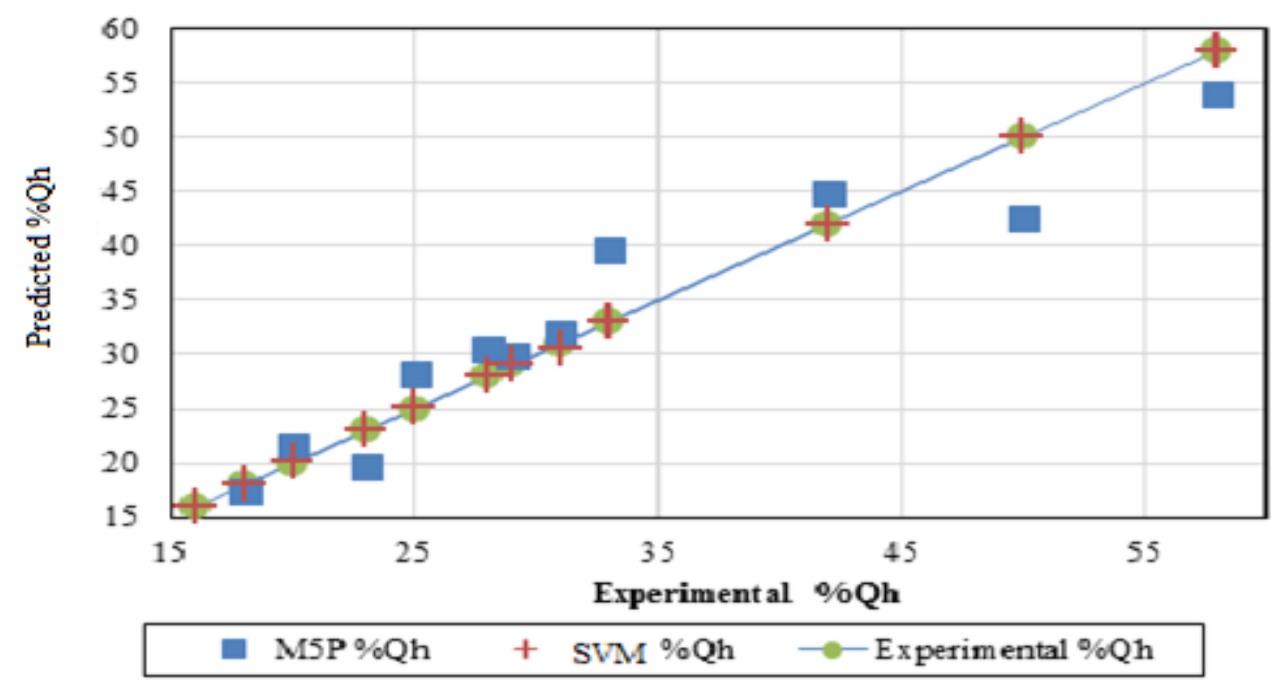

Figure 10. Experimental and predictive $\% \mathrm{Q}_{\mathrm{h}}$ values

Among the $\% \mathrm{Q}_{\mathrm{h}}$ values estimated in Figure 10, the increase values modeled with SVM are very close to the $\% \mathrm{Q}_{\mathrm{h}}$ calculated with experimental data. In general, when Figure 10 is examined, it can be seen that the predictive values are quite close to the experimental values. This shows that suitable parameters and appropriate algorithms are selected for modeling heat transfer treatment.

\section{CONCLUSIONS}

In all the experimental studies with turbulators, heat transfer was increased by at least $15 \%$ and at most $41 \%$ compared to experiments without turbulator. It was observed that pressure losses increased at the same rate. Considering the additional pressure loss rate of the net heat gain, it is seen that the turbulator with frequent bends in turbulators gives the best results. In all turbulators, including the 
frequently curved turbulator with the best heat transfer, the decreases in pressure loss as well as the thermal gain are seen to be small. According to the error analysis results of MAE (0.0439) and RMSE (0.0486) for the heat gain values, it can be said that the SVM algorithm makes a more successful prediction. More data can be obtained by using different types of turbulators and more successful predictive models can be created by using different computational intelligence methods.

\section{REFERENCES}

Abadi SMANR, Mehrabi M, Meyer JP, 2018, Prediction and optimization of condensation heat transfer coefficients and pressure drops of R134a inside an inclined smooth tube. International Journal of Heat and Mass Transfer Volume 124, September, Pages 953-966.

Akeel AM, Bashar AM and Raheem JM, 2014. Heat Transfer Enhancement in a Tube Fitted with NozzleTurbulators, Perforated Nozzle-Turbulators with Different hole shap. Eng. Tech.Journal, Vol. 32, Part (A), No.10.

Alic E, Das M, Kaska O, 2019. Heat Flux Estimation at Pool Boiling Processes with Computational Intelligence Methods. Processes, 7(5), 293.

Argunhan Z, Yıldız C, 2011. Dairesel Kesitli Bir Borunun Girişine Yerleştirilen Delikli Sabit Kanatçıklı Dönme Üreticinin Isı Geçişi Ve Basınç Düşüşüne Etkileri. Pamukkale Üniversitesi Mühendislik Bilimleri Dergisi, 12(2), 217-223.

Chokkıyee MKP, Balasuramanain R, Velusamy DD, 2020. Predictive Analysıs of Heat Transfer Characterıstics of Nanofluids in Helically Coiled Tube Heat Exchanger Using Regression Approach. Thermal Science International Scientific Journal, Volume 24, Issue 1, Pages: 505 - 513.

Çakmak G, 2000. Boru Girişinde Enjektörlü Türbülans Üreticisi Bulunan Isı Değiştirgeçlerinde Isı Transferinin ve Basınç Düşüşünün İncelenmesi, Yüksek Lisans Tezi. F.Ü. Fen Bilimleri Enstitüsü, Elazığ.

Çerçi K N, Daş M, 2019. Modeling of Heat Transfer Coefficient in Solar Greenhouse Type Drying Systems. Sustainability, 11(18), 5127.

Çirak B, Korcak S, 2017. Isı Transferinde Isı Kayıplarının Yapay Sinir Ağları Yöntemi ile İncelenmesi. Iğdır Üniversitesi Fen Bilimleri Enstitüsü Dergisi, 7(2), 185-197.

Çitlak A, Demirpolat AB, Das M, 2019. Katı Yakıtlı Bir Kazanda Isı Transferi İyileştirmeleri ve Basınç Farkının Yapay Sinir Ağı ile Modellenmesi. Frrat Üniversitesi Mühendislik Bilimleri Dergisi, 31 (2), 371-380. DOI: 10.35234/fumbd.509198.

Das M, Akpinar E K, 2018. Investigation of pear drying performance by different methods and regression of convective heat transfer coefficient with support vector machine. Applied Sciences, 8(2), 215.

Das M, Demirpolat AB, 2019. Bir Nanoakışkanın Farklı pH Değerlerindeki Isı Transfer Katsayılarının Belirlenmesi ve Karar Ağacı Algoritması ile Modellenmesi. Erzincan Üniversitesi Fen Bilimleri Enstitüsü Dergisi, 12 (2), 1056-1067. DOI: 10.18185/erzifbed.552293.

Daş M, Balpetek N, Kavak Akpinar E, Akpinar S, 2019. Türkiye'de bulunan farklı illerin rüzgâr enerjisi potansiyelinin incelenmesi ve sonuçların destek vektör makinesi regresyon ile tahminsel modelinin oluşturulması. Gazi Üniversitesi Mühendislik Mimarlık Fakültesi Dergisi, 34 (4).

Demirpolat A B, Das M, 2019. Prediction of viscosity values of nanofluids at different $\mathrm{pH}$ values by alternating decision tree and multilayer perceptron methods. Applied Sciences, 9(7), 1288.

Golgiyaz S, Talu M F, Onat C, 2019. Görüntü İşleme ve Makine Öğrenmesi Yöntemleri ile Baca Gazı Sicaklığının Tahmin Edilmesi. Avrupa Bilim ve Teknoloji Dergisi, (16), 283-291.

Guoqiang DSX Z, 2007. Heat transfer analysis using ANN with experimental data of $180^{\circ}$ turn channels with rib turbulators. Journal of Beijing University of Aeronautics and Astronautics, 4.

Holman JP, 1989. Experimental Methods for Engineers, 5th edition Mc-Graw Hill Company, New York. 
Ibrikçi T,Saçma S,Yıldırım V, Koca T, 2010. Application of Artificial Neural Networks in the Prediction of Critical Buckling Loads of Helical Compression Springs. Strojniški vestnik - Journal of Mechanical Engineering 56,6, 409-417.

Kakaç S, 1987. Isı İletimi, ODTÜ Mühendislik Fakültesi Yayınları, Yayın No: 52, Ankara.

Karagöz Ş, Abdi H, Ömeroğlu G, 2017. Experimental InvestigationOf The Effect Of Turbulators On Heat Transfer In Horizontal Tubes. Afyon Kocatepe Üniversitesi Fen Ve Mühendislik Bilimleri Dergisi, 17(2), 810-817.

Karagöz Ş, Çiltaş S, Yıldırım O, Erdoğan S, 2019. Yatay Borularda Türbülatörlerin Isı Transferine Olan Etkisinin Deneysel Araştırılması. Erzincan Üniversitesi Fen Bilimleri Enstitüsü Dergisi, 12(1), 306-316.

Karakaya H, Durmuş A, 2013. Heat transfer and exergy loss in conical spring turbulators. International Journal of Heat and Mass Transfer, 60, 756-762.

Kayataş N, İlbaş M, 2005. İç İçe Borulu Model Bir Isı Değiştiricisinde Isı Transferinin İyileştirilmesinin Sayısal Olarak İncelenmesi. Erciyes Üniversitesi Fen Bilimleri Enstitüsü Fen Bilimleri Dergisi, 21(1), 128-139.

Kikuyama K, Murakami M, Nishibori K, Maeda K, 1983. Flow in an Axially Rotating Pipe, Bulletin of The JSME Vol.26, No.214, April, 506-513.

Kline SJ and McClintock FA,1953. Describing Uncertainties in Single-Sample Experiments, Mechanical engineering, 75, 3-8.

Koca T, Zedeli A, 2020. Helisel İç Borulu Isı Değiştiricilerde Isı Transferi ve Basınç Düşümü Analizinin Deneysel Olarak İncelenmesi. Journal of the Institute of Science and Technology, 10(3): 1943-1955, 2020 ISSN: 2146-0574, eISSN: 2536-4618. DOI: 10.21597/jist.739873.

Kuzay TM, Scott CJ, 1977. Turbulent Heat Transfer Studies in Annulus With inner Cylinder Rotation, Journal of Heat Transfer, February 12-19.

Migay V K, Golubev LK, 1970. Friction and Heat Transfer in Turbulent Swirl Flow with a Variable Swirl Generator in A Pipe, Int. J. Heat Mass Transfer, Vol 2 No:3, May 68-73.

Moya-Rico JD, Molina AE, Belmonte J, Tendero JC, Almendros-Ibáñez JA, 2019. Characterization of a triple concentric-tube heat exchanger with corrugated tubes using Artificial Neural Networks (ANN). Applied Thermal Engineering; 147, 1036-1046.

Narezhnyy EG, Sudarev AV, 1971. Local Heat Transfer in Air Flowing in Tubes with a Turbulence Prometer at The Inlet, Int. J. Heat Mass Transfer, Vol.3 No:2, March-April 62-66.

Pal M, Mather PM, 2003. An assessment of the effectiveness of decision tree methods for land cover classification, Remote Sensing of Environment, vol.86, pp.554-565.

Panahi D, Zamzamian K, 2017. Heat transfer enhancement of shell-and-coiled tube heat exchanger utilizing helical wire turbulator. Applied Thermal Engineering, 115, 607-615.

Smithberg E, Landis F, 1964 . Friction and Forced Convection Heat Transfer Characteristics in Tubes with Twisted Tape Swirl Generators, Journal of Heat Transfer, February 39-49.

Smola AJ and Schölkopf BA, 2004. Tutorial on Support Vector Regression, Statistics and Computing., 14. 199222.

Sparrow EM, Chaboki A, 1984. Turbulent Fluid Flow and Heat Transfer in a Circular Tube. ASME Journal of Heat Transfer; 106, 766-773.

Sungur B, Topaloğlu B, 2018. Boru İçine Yerleştirilen Konik Türbülatör Sayısının Nümerik Optimizasyonu. Technological Applied Sciences, 13(3), 208-218.

Sungur B, Topaloglu B, Ozcan H, Namli L, 2018. Numerical analysis of the effect of conical turbulators to heat transfer performance of a liquid fuelled boiler. Research on Engineering Structures and Materials, 4(2), 127.

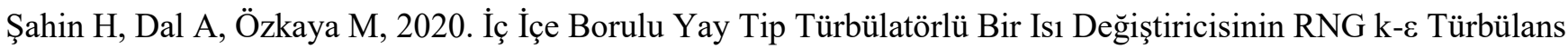
Modeli ile Sayısal Analizi. Gazi Üniversitesi Fen Bilimleri Dergisi Part C: Tasarım ve Teknoloji, 8 (1), 64-78. DOI: 10.29109/gujsc.625585. 
Tokgoz N, Alıç E, Kaşka Ö, Aksoy MM, 2018. The Numerical Study of Heat Transfer Enhancement Usıng $\mathrm{AL}_{2} \mathrm{O}_{3}$-Water Nanofluid in Corrugated Duct Application. Journal of Thermal Engineering, Vol. 4, No. 3, pp. 1984-1997, April, Yildiz Technical University Press, Istanbul, Turkey

Uğurlubilek N, Nuralcan IYY, 2011. Halisel Türbülatörün Isı Geçmişine Etkisinin Sayısal İncelenmesi. Eskişehir Osmangazi Üniversitesi Mühendislik ve Mimarlık Fakültesi Dergisi, 24(2), 71-84.

Vapnik V, 1995. The Nature of Statistical Learning Theory. Springer-Verlag, New York.

Vapnik, VN, 1998. Statistical learning theory. New York: Wiley.

Verma TN, Nashine P, Singh DV, Singh TS, Panwar D ANN, 2017. Prediction of an experimental heat transfer analysis of concentric tube heat exchanger with corrugated inner tubes. Applied Thermal Engineering; 120, 219-227.

Yıldız C, Biçer Y, Pehlivan D, 1998. Effect of Twisted Strips on Heat Transfer and Pressure Drop in Heat Exchanger. Energy Conversion and Management; 39, 331-336.

Yılmaz T, Ayhan T, 1983. Birbirleriyle Bağlantılı Daralan -Genişleyen Kanallarda Isı Transferi, Isı Bilimi ve Tekniği 4. Ulusal Kongresi; 133-149. 